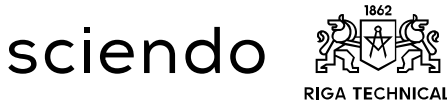 \\ RIGA TECHNICAL
UNIVERSITY
}

ISSN 2256-0394 (online)

ISSN 2256-0386 (print)

2019, 33, 192-206

doi: 10.2478/eb-2019-0014

https://content.sciendo.com

\section{INDUSTRY 4.0 AS THE DRIVING FORCE OF SME INTERNATIONALISATION: A CASE OF LITHUANIA}

\author{
Kristina KOVAITE் ${ }^{1}$, Paulius ŠŨMAKARIS ${ }^{2}$, Jelena STANKEVIČIENÉ ${ }^{3}$, \\ Renata KORSAKIENE $\dot{H}^{4}$
}

\author{
Vilnius Gediminas Technical University, Vilnius, Lithuania \\ Corresponding author's e-mail: kristina.kovaite@vgtu.lt
}

\begin{abstract}
Small and medium-sized enterprises (SMEs) are assumed to be one of the key contributors to the country's economic growth and social welfare. Thus, their internationalisation appears to be inevitable considering how globalisation processes have changed the rules of competition in recent decades. Smart and digitalised technologies (Internet of Things and Services, etc.) decentralise communication and provide the opportunities for new firms to overcome the barriers of geographical location and access international markets through cocreation business models and changes of the value chains. The paper aims at analysing and disclosing how the fourth industrial revolution (Industry 4.0) influences SME internationalisation. The present study is grounded on the research of extant scientific literature and assessment of experts. The research demonstrates that Industry 4.0 positively influences the internationalisation of SMEs on a number of dimensions. The recommendations for managers and policymakers how to foster internationalisation of SMEs are suggested.
\end{abstract}

Keywords: Business Model, Industry 4.0., SME Internationalisation, Smart and Interconnected Technologies

JEL Classification: D81, F23, F61

\section{INTRODUCTION}

The fourth industrial revolution (Industry 4.0) indicates a new paradigm of global technological developments in industry, society and business. Li (2018), Xu et al. (2018), Roblek et al. (2016) analysed a number of technological drivers, such as the Internet of Things (IoT), big data, artificial intelligence etc. The scholars encouraged investigations on the impact of business models, which include fusion of people and machines, the disappearance of physical boundaries of business ecosystem and decentralisation of communication system.

The drivers of Industry 4.0 allow disrupting business models in almost any industry and, thus, physical and geographical boundaries of industries disappear (Schwab, 2017; Porter \& Heppelmann, 2015). Moreover, the opportunities in newly established supply chains provide possibilities for SMEs to compete in international markets.

SMEs are significant players in almost all countries. For instance, the export of SMEs increased by $20 \%$ in the period of last five years and reached almost $60 \%$ of total export in Lithuania in 2017. In some cases, international expansion requires 
making investment decisions and, thus, the management of SMEs has to be able to identify priorities. While multinational companies have the resources to expand their activities abroad, SMEs usually lack a number of necessary resources and capabilities. These decisions are risky due to the required cash flow, human resources and expertise. Notably, the researchers focus on both traditional and non-traditional means of internationalisation.

The paper aims at contributing to the prevailing studies in economic and management by investigating the factors enabling SME internationalisation and using a business model driven by Industry 4.0. The research question is as follows: Which parts of the business model are the most influenced by enabling factors if SME internationalises its activities through business model under conditions of Industry 4.0 ?

\section{INDUSTRY 4.0 AS THE DRIVER OF SME INTERNATIONALISATION}

Different definitions of Industry 4.0 have been used in the scientific literature since 2015. The definition of Industry 4.0 was suggested in Germany and indicated smart and digitalised industrial changes and - further on - economy in general. Thus, the phenomenon of Industry 4.0 has been extensively investigated by the German researchers such as Brettel et al., 2014; Kagermann et al., 2013; Bauernhansl et al., 2014; Kagermann, 2015; Burmeister et al., 2015.

Industry 4.0 transforms business models through technological drivers, such as Internet of Things (Dujin et al., 2014; Liao et al., 2017; Zhou et al., 2016), cloud technology (Liao et al., 2017; Zhou et al., 2016), big data (Liao et al., 2017; Zhou et al., 2016); artificial intelligence (Schwab, 2017; Liao et al., 2017), and related issues.

The multiple studies emphasise the re-modelling of the value chain, diminishing significance of geographical place and increasing access to international markets for SMEs. The readiness and capability to meet these challenges depend on the firm's size. The smaller size of SMEs means the higher risk instead of beneficiaries of this revolution as Sommer (2015b) argues.

\section{THEORETICAL BACKGROUND ON SME INTERNATIONALISATION}

Internationalisation is not a new phenomenon and a common practice of the firms. Notably, throughout the time span, different approaches and definitions were developed. Table 1 provides an overview of the prevailing definitions of internationalisation.

Kos-Łabędowicz (2013) distinguished four paths of internationalisation:

1. through extending currently existing networks;

2. through gradual expansion to the closest geographical markets;

3. through dynamic market penetration when the conditions become more appropriate;

4. through dynamic penetration by early adaptation of new technologies.

While the first two approaches are examples of gradual stage theory, the last two are more organic and useful in the firms, which adopt e-commerce. 
Table 1. The Definitions of Internationalisation (developed by authors, 2019)

\begin{tabular}{|l|l|}
\hline \multicolumn{1}{|c|}{ Researchers } & \multicolumn{1}{c|}{ Definitions } \\
\hline (Zapletalová, 2015) & $\begin{array}{l}\text { Internationalisation is seen as the behaviour of entrepreneurial } \\
\text { subjects when they start their foreign operations. }\end{array}$ \\
\hline (Dominguez \& Mayrhofer, & $\begin{array}{l}\text { Internationalisation is a process of increasing commitments to } \\
\text { foreign markets. }\end{array}$ \\
\hline (Chen et al., 2016) & $\begin{array}{l}\text { Expansion into international markets has become an economic } \\
\text { necessity for today's firms, internationalisation provides firms } \\
\text { with the opportunity for growth, the ability to acquire knowledge } \\
\text { and access to new resources in foreign locations and the potential } \\
\text { for long-term profitability. }\end{array}$ \\
\hline (Dawei, 2008) & $\begin{array}{l}\text { Internationalisation is a process by which firms both increase their } \\
\text { awareness of the direct and indirect influences of international } \\
\text { transactions on their future, and establish and conduct transactions } \\
\text { with other countries. }\end{array}$ \\
\hline (Skudiene et al., 2015) & $\begin{array}{l}\text { Internationalisation is primarily understood as an outward } \\
\text { movement process of a firm's international operations. }\end{array}$ \\
\hline (Demeke \& Chiloane- & $\begin{array}{l}\text { Internationalisation is a term that has been used widely in the } \\
\text { literature and is not only confined to exporting but also } \\
\text { encompasses trade, cross-border clustering, collaboration, } \\
\text { alliances, subsidiaries, branches, and joint ventures that extend } \\
\text { beyond the home country environment. }\end{array}$ \\
\hline (Manolova et al., 2002) & $\begin{array}{l}\text { Internationalisation is approached using three distinct, but } \\
\text { interrelated, perspectives: internationalisation process, export } \\
\text { development, and international entrepreneurship. }\end{array}$ \\
\hline
\end{tabular}

The operating principles of SMEs have changed fundamentally due to unprotected market and fully occupied business niches. Therefore, internationalisation and search of foreign markets are seen as an inevitable challenge of SMEs. SMEs are driven to operate beyond the domestic market due to the possibility to access resources, such as finances, capital and know-how (Ratten et al., 2007).

The investigation of the success factors is crucial for the survival and competitiveness of SMEs in the global markets. Not going deep in the prevailing literature, the study is grounded on three internal and three external factors (Fig. 1), which have a positive impact on internationalisation of SMEs:

1) Internal factors:

- Technological transformation;

- Financial capacity;

- Internal expertise and competences.

2) External factors:

- Networking;

- Economic environment;

- Market dynamics. 


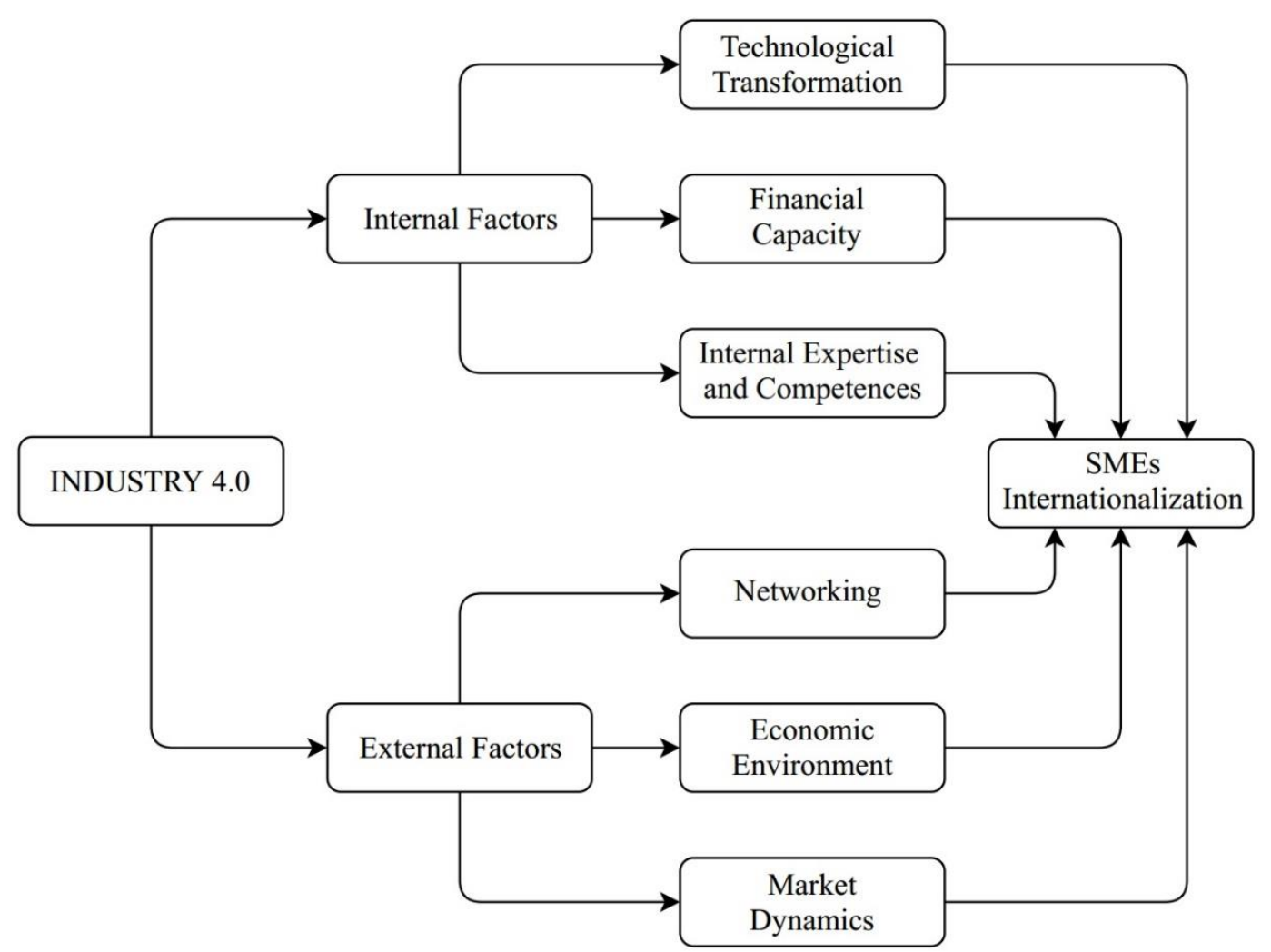

Fig. 1. SME internationalisation: 6-factor model (created by the authors, 2019).

Technological transformation includes SME IT infrastructure, technological capabilities, data availability, big data analytics, IoT, R\&D activities, digitalisation processes and connected devices, enhancing information technology services. Ratten et al. (2007) found that companies operating in technology-intensive industries were willing to internationalise their activity in order to either minimise $R \& D$ costs or gain access to resources. Technological advances in information and communication technology (ITC) transformed a value chain. Digital connectivity promotion by decreasing the cost to access to digital infrastructure and increasing the quality will empower SMEs to take full advantage of the digital trade revolution (OECD, 2017). This leads to an increase in exports and imports.

Financial capacity includes SME financial resources, cash flows, investment availability and the potential to acquire financial resources. Ratten et al. (2007) found that the company's financial resources and capabilities were important determinants of internationalisation and success. The studies demonstrate how value creation can be developed through access to resources, such as the specific financial products, e.g., export credit and insurance, which are crucial for running business outside domestic market (OECD, 2015).

Internal expertise and competences include knowledge and experience of owners and employees, organisational structure, procedures, culture, tolerance to change, motivation, ability to work remotely and training. Internal challenges refer to the issues, such as a lack of scale or experience, low productivity and lagging adoption of technology (López González \& Sorescu, 2019). The firms sustain competitive 
advantage because of their own know-how: rare non-substitutable, and difficult to imitate resources (Wong, 2011). SMEs expand the activities to more distant markets by creating the possibility to use the accumulated knowledge and experience (Dominguez \& Mayrhofer, 2017). According to Ratten et al. (2007), the companies recognise new opportunities in foreign markets due to investment in research, development, training, stock of knowledge and learning.

Networking includes personal contacts of owners and managers, potential to make new connections, maintain and develop existing ones. Johanson and Mattsson (1988) argue that while the amount and strength of contacts in the network increase, the firms internationalise further. Lofgren et al. (2008) confirmed that the use of business networks or membership in a cluster is crucial in SME internationalisation. Ratten et al. (2007) investigated the importance of networking. The development of financial, technological, and commercial relationships with network partners enables companies to expand activities from their own territory (Laghzaoui, 2011). The opportunity to create networks and conduct exchanges with partners is a key factor for international success (Acosta et al., 2018).

Economic environment includes foreign economic and business policy environment, economic and business policy environment for entering international markets (Affendy \& Shamsudin, 2015), the pull factors that attract the firms, such as purchasing power, GDP growth, declining trade and investment barriers, improved regulation, tax incentives for SMEs, which support internationalisation.

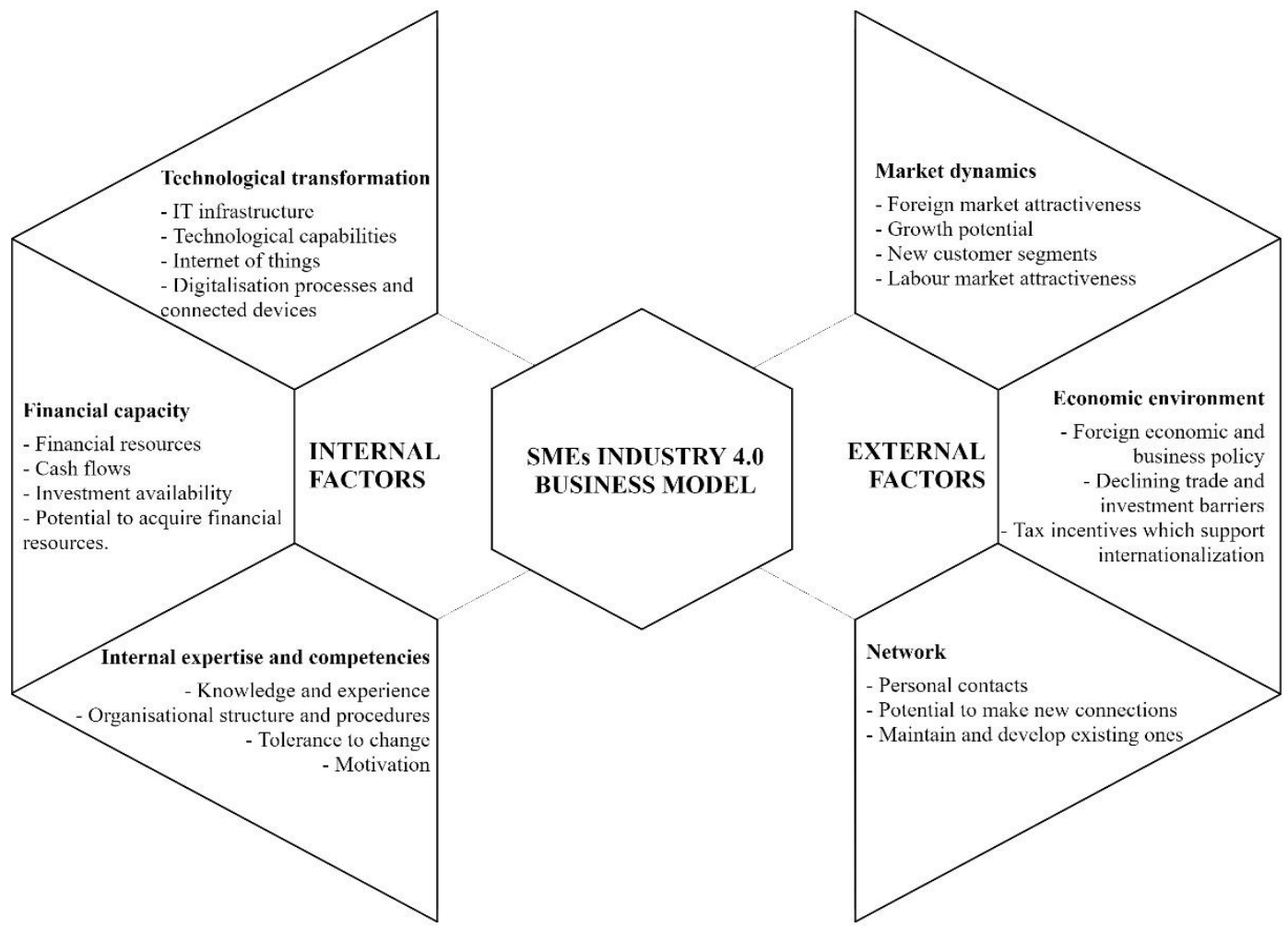

Fig. 2. The most important elements of internal and external factors on SME internationalisation in the context of Industry 4.0 business model change (created by the authors, 2019). 
Market dynamics includes foreign market attractiveness, growth potential, new customer segments, labour market attractiveness, a shift of consumer consumption, the potential of differentiation, and customer loyalty. Sekliuckiene (2013) suggests that the high potential of rapidly increasing middle class is also important. According to Tatoglu et al. (2003), foreign country market-specific factors were more significant than domestic or firm-specific motives of internationalisation.

In conclusion, the analysis of the most important factors is crucial for SME internationalisation success. Figure 2 specifies the relevant components of internal and external factors that have been included in the further research of this paper.

\section{MATERIALS AND METHODS}

The globalisation processes have been accelerating in Lithuania since the accession to the European Union in 2004. In Lithuania, SMEs are defined by the Law of Small and Medium-Sized Business Development. Table 2 presents the criteria distinguishing micro, small and medium-sized enterprises.

Table 2. The Criteria of SMEs (Ministry of the Economy and Innovation of the Republic of Lithuania, 2019)

\begin{tabular}{|l|l|c|c|}
\hline \multirow{2}{*}{ Type of company } & Staff headcount & \multicolumn{2}{|c|}{$\begin{array}{r}\text { Financial indicators meeting at least one of } \\
\text { these requirements }\end{array}$} \\
\cline { 3 - 4 } & & $\begin{array}{c}\text { Annual turnover, } \\
\text { million EUR }\end{array}$ & $\begin{array}{c}\text { Balance sheet total, } \\
\text { million EUR }\end{array}$ \\
\hline $\begin{array}{l}\text { Medium-sized } \\
\text { enterprise }\end{array}$ & Fewer than 250 & 50 & 43 \\
\hline Small enterprise & Fewer than 50 & 10 & 10 \\
\hline Microenterprise & Fewer than 10 & 2 & 2 \\
\hline
\end{tabular}

According to the Department of Statistics of Lithuania, the number of operating enterprises is 105 053, of which SMEs comprise 104566 (99.50 \%). Among SMEs, $100576(95.74 \%)$ are small enterprises with up to 50 employees. SME growth and internationalisation are supported by the European Union Regional Development and Social Funds.

The analysis of scientific literature and the developed 6-factor model enabled us to define the following research steps.

1. Development of the template.

The number of relationships between criteria should be reasonable and calculated when developing an expert evaluation template.

$$
R=\frac{m(m-1)}{2}
$$

An increase in a number of relationships $m$ when increasing the number of criteria at least by one is observed, e.g., 9 criteria create 36 relationships for expert evaluation and 10 criteria would create 45 relationships. 
2. FARE (Factor relationship) method is used for expert evaluation. Ten experts were selected for the research. The experts were selected according to the following criteria: 1) each expert represents a different economic area; 2) each expert has at least 10 years of experience in managing SME; 3 ) each of experts has experience of implementing initiatives related to Industry 4.0.

The selection of experts and the evaluation were carried out strictly according to the requirements of the methodology explained by Ginevičius (2011). The scholar explained the FARE method as "the difference between the weights calculated by FARE and the criteria weights obtained by AHP technique is the smallest compared to other methods". FARE method is based on the interrelationships between all the criteria compared to each other towards the object considered.

The experts were instructed about the methodology and provided with six excel forms; each form collected data for a separate enabling factor. Experts were asked to compare each business model block with another and valuate the comparison between 0 and 5, with 0 representing no difference between the two criteria and 5 representing a very large difference between the two criteria.

Evaluation was carried out as the individual expert work, and they were not influenced by other experts. The main research question to answer was formulated the following: Which block of business model is more influenced by a specific enabling factor when SMEs internationalise their digitalised business model driven by Industry 4.0 ?

Only final results after numerous steps of data processing are presented in this article.

The weighted average values were calculated and transferred to Table 5.

The normalisation of the potential values of the total impact of the criteria to the effect on the test object is calculated as follows:

$$
w_{i}=\frac{P_{i}^{f}}{P_{S}}=\frac{P_{1}-m a_{1 i}+S(m-1)}{m S(m-1)} .
$$

The total potential required to determine the criteria weights was calculated from the data collected by the expert judgment from the summary of the criteria potential equilibrium matrix $P_{i}=P_{1}-m^{*} a_{1 i}$, where $P_{i}-$ the total impact of the $i^{\text {th }}$ criterion.

The sum of the total impact values ( $P_{i}$ ) of the individual system criteria on the research object is equal to zero:

$$
\sum_{i=1}^{m} P_{i}=\sum_{i=1}^{m}\left(P_{1}-m a_{1 i}\right)=m P_{1}-m \sum_{i=1}^{m} a_{i}=m P_{i}-m P_{1}=0
$$

where

$P_{i}$ - the total impact;

$m$ - the number of relationships;

$a_{1 i}$-the value of the matrix element of the $i^{\text {th }}$ row of the $j^{\text {th }}$ column; $a_{1 j}$ and $a_{1 i}$ - the first row elements.

When creating a template, the same criteria should be horizontal and vertical. 


$$
w_{i}=\frac{P_{i}^{f}}{P_{S}}=\frac{P_{1}-m a_{1 i}+S(m-1)}{m S(m-1)}
$$

4. Kendall's coefficient (Podvezko, 2004; Kendall, 1955) is used to evaluate the concordance of expert assessments. The coefficient values are from 0 to 1 . The Kendall W compatibility factor close to 1 indicates that the experts' estimates are unanimous and close to 0 shows that there is considerable variation in expert judgment.

The Kendall coefficient is calculated using the following formula:

$$
W=\frac{12 S}{r^{2} n\left(n^{2}-1\right)-r \sum_{j=1}^{r} T_{j}^{\prime}},
$$

where

$r-$ a number of experts;

$n-$ a number of objects to evaluate

$$
\mathrm{S}=\sum_{\mathrm{i}=1}^{\mathrm{m}}\left(e_{i}-\bar{e}\right)
$$

where

$\mathrm{S}$ - a sum-of-squares statistic over the row sums of ranks $m_{i}$;

$e_{i}-$ a sum of ranks;

$\bar{e}$ - average of sums of ranks .

$$
T_{j}=\sum_{k=1}^{H j}\left(t_{k}^{3}-t_{k}\right)
$$

where

$T-$ an indicator of tied ranks of $\mathrm{j}$ expert;

$H$ - a number of ranks of the same value of the j expert;

$t_{k}$ - a number of equal tied ranks in each $(k)$ group of ties.

$$
C h i S q=W r(m-1)
$$

5. Data obtained by estimating the relationship between the criteria using the FARE method are evaluated in the developed 6-factor model.

\section{RESULTS}

FARE method allows observing the interrelatedness between the parts of the business model. Table 3 identifies the value proposition as a key criterion after expert evaluation.

In a row "Relationship between the main criterion and other criteria", blue colour means positive relation between the main criterion and a specific criterion, red colour means negative relation of the same and a number means the strength of the relation. 
Table 3. The Relationship between the Main Criterion and Other Criteria and Weights (developed by the authors, 2019)

\begin{tabular}{|l|l|l|l|l|l|l|l|l|l|}
\hline & $\begin{array}{l}\text { 1. key } \\
\text { partners }\end{array}$ & $\begin{array}{l}\text { 2. key } \\
\text { activities }\end{array}$ & $\begin{array}{l}\text { 3. key } \\
\text { resources }\end{array}$ & $\begin{array}{l}\text { 4. value } \\
\text { propositio } \\
\text { n }\end{array}$ & $\begin{array}{l}\text { 5. } \\
\text { customer } \\
\text { relationshi } \\
\text { p }\end{array}$ & $\begin{array}{l}\text { 6. } \\
\text { customer } \\
\text { channels }\end{array}$ & $\begin{array}{l}\text { l. } \\
\text { customer } \\
\text { segments }\end{array}$ & $\begin{array}{l}\text { 8. revenue } \\
\text { stream }\end{array}$ & $\begin{array}{l}\text { 9. cost } \\
\text { structure }\end{array}$ \\
\hline value & 11.2 & 8.6 & -1.4 & 0 & 7.9 & 8.1 & 6.2 & 10.5 & 11.3 \\
\hline dependence & 8.82 & 6.77 & -1.10 & 0.00 & 6.22 & 6.38 & 4.88 & 8.27 & 10.00 \\
\hline weights & 0.07 & 0.1 & 0.05 & 0.08 & 0.11 & 0.22 & 0.15 & 0.09 & 0.13 \\
\hline
\end{tabular}

A positive relation here means that a specific criterion has a weaker relationship with the main criterion and the main criterion is stronger. Negative relations means that a specific criterion is less influenced by factors than the main criterion. A smaller number means closer relationship between a specific and the main criterion. In addition to colour, a numeric evaluation is provided for the comparison purpose.

For example, cost structure has a valuation of 10 and is identified as having the weakest relationship with the main criterion. Key resources - the strongest relationship with the main criterion.

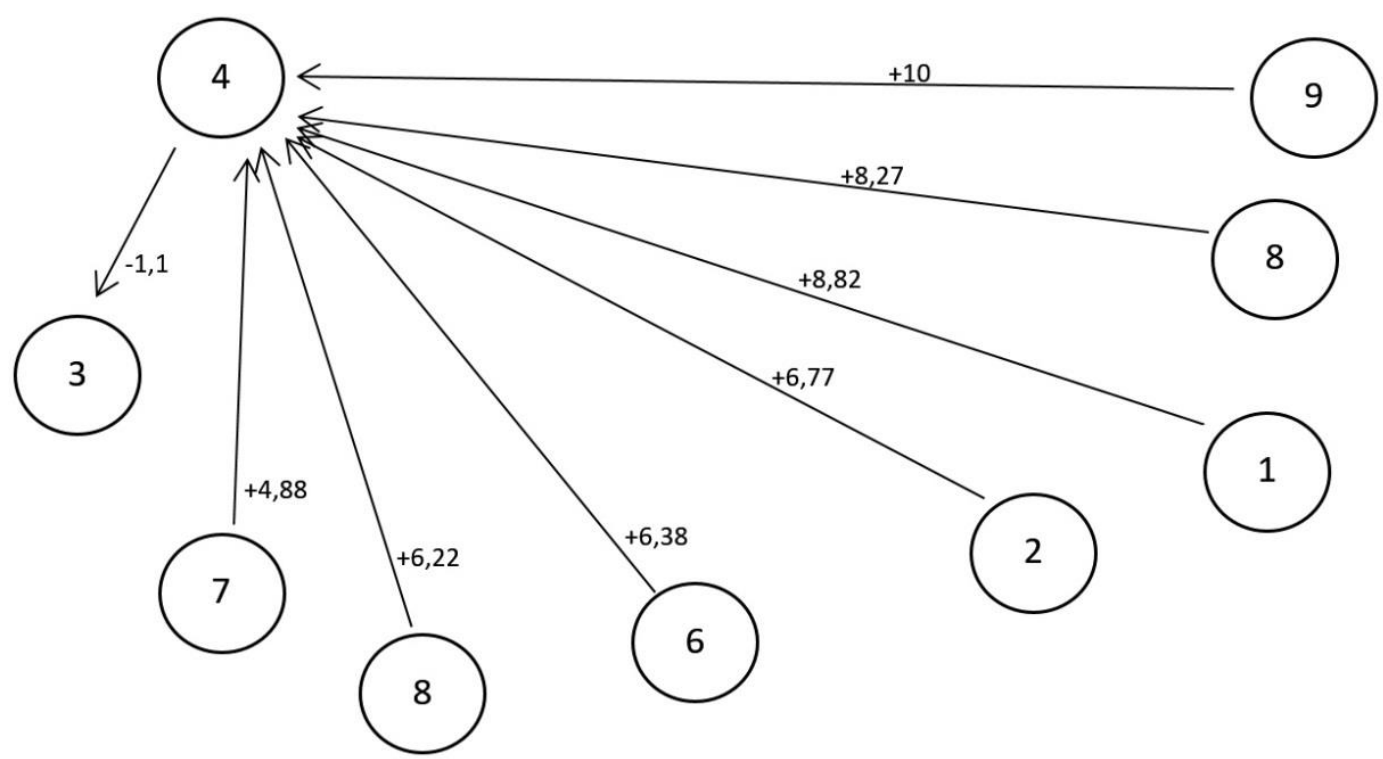

Fig. 3. The visualisation of the relationship between the main criterion and other criteria and weights (developed by the authors, 2019).

The direction of the arrow (Fig. 2) indicates the relationship between the criteria. Thus, the arrow goes from stronger criteria, i.e., a criterion that has more influence. The results are presented in Tables 4 and 5.

The results in Table 4 show the influence of specific enabling factor (horizontal) on each canvas block of the business model (vertical). Red indicates a lower influence in the business model canvas block and blue indicates a higher influence in the block. 
Table 4. The Results of the 6-factor Model (developed by the authors, 2019)

\begin{tabular}{|c|c|c|c|c|c|c|c|}
\hline $\begin{array}{l}\text { Business model } \\
\text { canvas blocks }\end{array}$ & weight & \begin{tabular}{|l} 
Financial \\
capacity
\end{tabular} & \begin{tabular}{|l} 
Internal \\
expertise and \\
competences
\end{tabular} & $\begin{array}{l}\text { Technologica } \\
1 \\
\text { transformatio }\end{array}$ & Networking & $\begin{array}{l}\text { Economic } \\
\text { environment }\end{array}$ & \begin{tabular}{|l|} 
Market \\
dynamics
\end{tabular} \\
\hline \begin{tabular}{|l|} 
cost structure \\
\end{tabular} & 0.06 & -99 & -93 & -97 & $\frac{-161}{-16}$ & -94 & $-7 \overline{4}$ \\
\hline customer channels & 0.15 & 39 & -25 & 50 & -62 & 117 & 124 \\
\hline \begin{tabular}{|l|} 
customer \\
\end{tabular} & 0.1 & 40 & 37 & 30 & -110 & -67 & 37 \\
\hline customer segments & 0.1 & 2 & -8 & 34 & -68 & 176 & 118 \\
\hline key activities & 0.15 & 13 & -7 & 69 & -13 & 21 & -38 \\
\hline key partners & 0.1 & -237 & -200 & -117 & 270 & -251 & -239 \\
\hline key resources & 0.12 & 235 & 136 & -62 & 102 & 17 & -7 \\
\hline revenue stream & 0.08 & $\begin{array}{l}-77 \\
\end{array}$ & -2 & -44 & $-3 \sqrt{1}$ & -18[ & 10 \\
\hline value proposition & 0.14 & 84 & 162 & 137 & 73 & 99 & 69 \\
\hline
\end{tabular}

Value proposition has the highest influence in each enabling factor category and overall influence of value proposition is positive. Other major influence areas come with customer channels, customer relationship, key resources, customer segment having high scores in 4 categories.

Cost structure shows the lowest influence in all enabling factors.

Key partners show very high influence in the networking category and low influence in all the other categories.

Table 5. The Total Effect (Dependence) of the Criteria Describing the Research Object (developed by the authors, 2019)

\begin{tabular}{|l|r|r|r|r|r|r|r|r|r|r|r|r|}
\hline $\begin{array}{l}\text { All the } \\
\text { enablers }\end{array}$ & $\begin{array}{c}\text { key } \\
\text { partne } \\
\text { rs }\end{array}$ & $\begin{array}{c}\text { key } \\
\text { activi } \\
\text { ties }\end{array}$ & $\begin{array}{c}\text { key } \\
\text { resour } \\
\text { ces }\end{array}$ & $\begin{array}{c}\text { value } \\
\text { propo } \\
\text { sition }\end{array}$ & $\begin{array}{c}\text { custo } \\
\text { mer } \\
\text { relati } \\
\text { onshi } \\
\text { p }\end{array}$ & $\begin{array}{c}\text { custo } \\
\text { mer } \\
\text { chann } \\
\text { els }\end{array}$ & $\begin{array}{c}\text { custo } \\
\text { mer } \\
\text { segm } \\
\text { ents }\end{array}$ & $\begin{array}{c}\text { reven } \\
\text { ue } \\
\text { strea } \\
\text { m }\end{array}$ & $\begin{array}{c}\text { cost } \\
\text { structu } \\
\text { re }\end{array}$ & weight & pf & $\begin{array}{c}\text { total } \\
\text { depen } \\
\text { dence }\end{array}$ \\
\hline key partners & 0 & -9.1 & -12.6 & -11.2 & -10.4 & -10.6 & -11.2 & -8.2 & -4.1 & 0.1 & -30.6 & -77.4 \\
\hline $\begin{array}{l}\text { key } \\
\text { activities }\end{array}$ & 9.1 & 0 & -3.4 & -8.6 & 1 & -2.9 & -1.1 & 1.1 & 9.3 & 0.15 & 39.6 & 2.25 \\
\hline $\begin{array}{l}\text { key } \\
\text { resources }\end{array}$ & 12.6 & 3.4 & 0 & 1.4 & 2.9 & 2.6 & 1.6 & 6 & 11.6 & 0.12 & 95.8 & 50.52 \\
\hline $\begin{array}{l}\text { value } \\
\text { proposition }\end{array}$ & 11.2 & 8.6 & -1.4 & 0 & 7.9 & 8.1 & 6.2 & 10.5 & 11.3 & 0.14 & 110.9 & 93.6 \\
\hline $\begin{array}{l}\text { customer } \\
\text { relationship }\end{array}$ & 10.4 & -1 & -2.9 & -7.9 & 0 & -5.1 & -5 & 0.9 & 7.3 & 0.1 & 46 & -4.62 \\
\hline $\begin{array}{l}\text { customer } \\
\text { channels }\end{array}$ & 10.6 & 2.9 & -2.6 & -8.1 & 5.1 & 0 & 2.2 & 5 & 9.2 & 0.15 & 74.3 & 38.88 \\
\hline $\begin{array}{l}\text { customer } \\
\text { segments }\end{array}$ & 11.2 & 1.1 & -1.6 & -6.2 & 5 & -2.2 & 0 & 8.5 & 9.6 & 0.1 & 75.7 & 38.1 \\
\hline $\begin{array}{l}\text { revenue } \\
\text { stream }\end{array}$ & 8.2 & -1.1 & -6 & -10.5 & -0.9 & -5 & -8.5 & 0 & 7.6 & 0.08 & 32.9 & -9.72 \\
\hline $\begin{array}{l}\text { cost } \\
\text { structure }\end{array}$ & 4.1 & -9.3 & -11.6 & -11.3 & -7.3 & -9.2 & -9.6 & -7.6 & 0 & 0.06 & -13.5 & -43.26 \\
\hline
\end{tabular}

Source: elaborated by the authors on the basis of expert evaluation using FARE method, 2019.

Table 5 shows the results of studies using the FARE method. The results show the relationship between business model blocks across all 6 factors. A positive number indicates a lower dependence of the horizontally labelled block relative to 
the vertical block. A negative number indicates a greater dependence of the horizontally labelled block relative to the vertical block.

Table 6. The 6-factor Model (developed by the authors, 2019)

\begin{tabular}{|l|l|l|l|l|l|l|}
\hline $\begin{array}{l}\text { Business model } \\
\text { canvas blocks }\end{array}$ & $\begin{array}{l}\text { Financial } \\
\text { capacity }\end{array}$ & $\begin{array}{l}\text { Internal } \\
\text { expertise and } \\
\text { competences }\end{array}$ & $\begin{array}{l}\text { Technologi- } \\
\text { cal } \\
\text { transforma- } \\
\text { tion }\end{array}$ & $\begin{array}{l}\text { Networ- } \\
\text { king }\end{array}$ & $\begin{array}{l}\text { Econo- } \\
\text { mic } \\
\text { environ- } \\
\text { ment }\end{array}$ & $\begin{array}{l}\text { Market } \\
\text { dynamics }\end{array}$ \\
\hline cost structure & 2.92 & 2.96 & 0.79 & 0.00 & 3.68 & 4.55 \\
\hline $\begin{array}{l}\text { customer } \\
\text { channels }\end{array}$ & 5.85 & 4.83 & 6.57 & 2.30 & 8.62 & 10.00 \\
\hline $\begin{array}{l}\text { customer } \\
\text { relationship }\end{array}$ & 5.87 & 6.55 & 5.79 & 1.18 & 4.31 & 7.60 \\
\hline $\begin{array}{l}\text { customer } \\
\text { segments }\end{array}$ & 5.06 & 5.30 & 5.94 & 2.16 & 10.00 & 9.83 \\
\hline key activities & 5.30 & 5.33 & 7.32 & 3.43 & 6.37 & 5.54 \\
\hline key partners & 0.00 & 0.00 & 0.00 & 10.00 & 0.00 & 0.00 \\
\hline key resources & 10.00 & 9.28 & 2.17 & 6.10 & 6.28 & 6.39 \\
\hline revenue stream & 3.39 & 5.47 & 2.87 & 3.02 & 5.46 & 6.86 \\
\hline $\begin{array}{l}\text { value } \\
\text { proposition }\end{array}$ & 6.80 & 10.00 & 10.00 & 5.43 & 8.20 & 8.48 \\
\hline
\end{tabular}

Table 6 is made using Excel function Conditional formatting. Data collected after the expert evaluation was normalised. Valuation 10 represents the highest level of influence by a factor in the column, while valuation 0 represents the lowest level of influence in the column, e.g., the highest influence by technological transformation is seen for value proposition (value 10 coloured in green) and the lowest influence by technological transformation is seen for the key partners (value 0 coloured in red).

Table 7. Division of Blocks of Business Model among Enabling Factors (developed by the authors, 2019)

\begin{tabular}{|c|c|c|c|c|c|c|}
\hline $\begin{array}{l}\text { Influence } \\
\text { level }\end{array}$ & $\begin{array}{l}\text { Financial } \\
\text { capacity }\end{array}$ & $\begin{array}{l}\text { Internal } \\
\text { expertise } \\
\text { and } \\
\text { competence } \\
\text { S }\end{array}$ & $\begin{array}{l}\text { Technologi } \\
\text { cal } \\
\text { transforma } \\
\text { tion }\end{array}$ & Networking & $\begin{array}{l}\text { Economic } \\
\text { environme } \\
\text { nt }\end{array}$ & $\begin{array}{l}\text { Market } \\
\text { dynamics }\end{array}$ \\
\hline \multirow{4}{*}{$\begin{array}{l}\text { High } \\
\text { influence, } \\
10-7.51\end{array}$} & $\begin{array}{l}\text { key } \\
\text { resources }\end{array}$ & $\begin{array}{l}\text { value } \\
\text { proposition }\end{array}$ & $\begin{array}{l}\text { value } \\
\text { proposition }\end{array}$ & key partners & $\begin{array}{l}\text { customer } \\
\text { segments }\end{array}$ & $\begin{array}{l}\text { customer } \\
\text { channels }\end{array}$ \\
\hline & & $\begin{array}{l}\text { key } \\
\text { resources }\end{array}$ & & & $\begin{array}{l}\text { customer } \\
\text { channels }\end{array}$ & $\begin{array}{l}\text { customer } \\
\text { segments }\end{array}$ \\
\hline & & & & & $\begin{array}{l}\text { value } \\
\text { proposition }\end{array}$ & $\begin{array}{l}\text { value } \\
\text { proposition }\end{array}$ \\
\hline & & & & & & $\begin{array}{l}\text { customer } \\
\text { relationship }\end{array}$ \\
\hline \multirow{4}{*}{$\begin{array}{l}\text { Higher } \\
\text { medium } \\
\text { influence, } \\
7.5-5.01\end{array}$} & $\begin{array}{l}\text { value } \\
\text { proposition }\end{array}$ & $\begin{array}{l}\text { customer } \\
\text { relationship }\end{array}$ & $\begin{array}{l}\text { key } \\
\text { activities }\end{array}$ & $\begin{array}{l}\text { key } \\
\text { resources }\end{array}$ & $\begin{array}{l}\text { key } \\
\text { activities }\end{array}$ & $\begin{array}{l}\text { revenue } \\
\text { stream }\end{array}$ \\
\hline & $\begin{array}{l}\text { customer } \\
\text { channels }\end{array}$ & $\begin{array}{l}\text { revenue } \\
\text { stream }\end{array}$ & $\begin{array}{l}\text { customer } \\
\text { channels }\end{array}$ & $\begin{array}{l}\text { value } \\
\text { proposition }\end{array}$ & $\begin{array}{l}\text { key } \\
\text { resources }\end{array}$ & key resources \\
\hline & $\begin{array}{l}\text { customer } \\
\text { relationship }\end{array}$ & $\begin{array}{l}\text { customer } \\
\text { segments }\end{array}$ & $\begin{array}{l}\text { customer } \\
\text { segments }\end{array}$ & & $\begin{array}{l}\text { revenue } \\
\text { stream }\end{array}$ & key activities \\
\hline & $\begin{array}{l}\text { customer } \\
\text { segments }\end{array}$ & $\begin{array}{l}\text { key } \\
\text { activities }\end{array}$ & $\begin{array}{l}\text { customer } \\
\text { relationship }\end{array}$ & & & \\
\hline
\end{tabular}




\begin{tabular}{|c|c|c|c|c|c|c|}
\hline & $\begin{array}{l}\text { key } \\
\text { activities }\end{array}$ & & & & & \\
\hline \multirow{2}{*}{$\begin{array}{l}\text { Lower } \\
\text { medium } \\
\text { influence, } \\
2.51-5\end{array}$} & $\begin{array}{l}\text { revenue } \\
\text { stream }\end{array}$ & $\begin{array}{l}\text { customer } \\
\text { channels }\end{array}$ & $\begin{array}{l}\text { revenue } \\
\text { stream }\end{array}$ & $\begin{array}{l}\text { revenue } \\
\text { stream }\end{array}$ & $\begin{array}{l}\text { customer } \\
\text { relationship }\end{array}$ & cost structure \\
\hline & $\begin{array}{l}\text { cost } \\
\text { structure }\end{array}$ & $\begin{array}{l}\text { cost } \\
\text { structure }\end{array}$ & & $\begin{array}{l}\text { key } \\
\text { activities }\end{array}$ & $\begin{array}{l}\text { cost } \\
\text { structure }\end{array}$ & \\
\hline \multirow{4}{*}{$\begin{array}{l}\text { Low } \\
\text { influence, } \\
0-2.5\end{array}$} & key partners & key partners & $\begin{array}{l}\text { key } \\
\text { resources }\end{array}$ & $\begin{array}{l}\text { customer } \\
\text { channels }\end{array}$ & key partners & key partners \\
\hline & & & $\begin{array}{l}\text { cost } \\
\text { structure }\end{array}$ & $\begin{array}{l}\text { customer } \\
\text { relationship }\end{array}$ & & \\
\hline & & & key partners & $\begin{array}{l}\text { customer } \\
\text { segments }\end{array}$ & & \\
\hline & & & & $\begin{array}{l}\text { cost } \\
\text { structure }\end{array}$ & & \\
\hline
\end{tabular}

The blocks of the business model after normalisation of valuations are divided into four groups according to different levels of influence.

\section{CONCLUSION}

The investigation has demonstrated that the success of SMEs is interrelated to the capability to transform and disrupt business models. Therefore, the internationalisation of SMEs has become a multidisciplinary scientific area and attracted significant attention of scholars.

The article contributes to the scientific literature and extends SME internationalisation enabling factors by the factor of technological transformation and suggests the 6-factor model. The internationalisation using the business model impacted by Industry 4.0 is distinguished as a gap in the scientific literature. The 6factor model is introduced and tested using the FARE method.

The article contributes to the decision-making of management by developing a decision support instrument. The enterprises can use the 6-factor model to plan internationalisation using a digital business model. The 6-factor model identifies the internal and external factors, which have the largest influence on specific parts of the business model.

The following parts of the business model are considered to be most influenced by all 6 factors (in the sequence from the highest to the lowest): value proposition, key resources, customer channels and customer segments. The block "key partners" is observed as the most influenced by the factor "networking" and the least influenced by all the rest factors. The rest blocks are seen of the medium or low influence.

The article contributes to policy decision-making. The policy-makers can use the 6-factor model to identify the priorities for SME internationalisation and Industry 4.0 implementation programmes or regional development.

The research presented in the article has some limitations. The 6-factor model covers the internal and external environment. The model does not divide factors into sub-factors. Thus, the integration of sub-factors could provide more accurate results. Taking into consideration further research, methodological procedures should be considered. The experts have to compare the interrelationship of factors using the FARE method. On the other hand, even one additional criterion dramatically increases multiple relationships. A higher number of criteria could result in the issues 
of data collection and interpretation. The influence of enabling factors on business models in different sectors and industries by applying the 6-factor model should be investigated with the aim to disclose differences. In addition, future studies could integrate the emerging concept of Industry 5.0 also known as Society 5.0, which focuses more on the social consequences of technological advancements.

\section{REFERENCES}

Affendy, A. H., Asmat-Nizam, A-T., \& Farid M. S. (2015). Entrepreneurial orientation effects on market orientation and performance relationship - A SEM approach. Rev. Integr. Bus. Econ. Res. 4(3), 259-271.

Chen, H-L., Hsu, W-T., \& Chang, C-Y. (2016). Independent directors' human and social capital, firm internationalization and performance implications: An integrated agencyresource dependence view. International Business Review, 25(4), 859-871. https://doi.org/10.1016/j.ibusrev.2015.10.010

Dawei, G. (2008). And Entry Strategy Of Enterprises : A Case study of Chinese firm : Huawei Supervisor: Gabriel Awuah. Perspective, 53, 1-53.

Demeke, Y., \& Chiloane-Tsoka, G. E. (2015). Internationalization drivers of small and mediumsized manufacturing enterprises in Ethiopia: The case of leather and leather products industry. Problems and Perspectives in Management, 13(4), 32-42.

Dominguez, N., \& Mayrhofer, U. (2017). Internationalization stages of traditional SMEs: Increasing, decreasing and re-increasing commitment to foreign markets. International Business Review, 26(6), 1051-1063. https://doi.org/10.1016/j.ibusrev.2017.03.010

Dujin, A., Geissler, C., \& Horstkötter, D. (2014). Industry 4.0 The new industrial revolution How Europe will succeed. Roland Berger Strategy Consultants, 1-24.

Ginevičius, R. (2011). A New Determining Method for the Criteria Weights in Multicriteria Evaluation. International Journal of Information Technology \& Decision Making, 10(6), 1067-1095. https://doi.org/10.1142/S0219622011004713

Kos-Łabędowicz, J. (2013). Influence of Modern Technologies on Internationalization of Small and Medium Enterprises. Information Systems in Management, 2(1), 12-22.

Laghzaoui, S. (2011). SMEs' internationalization: an analysis with the concept of resources and competencies. Journal of Innovation Economics, 7(1), 181.

Li, L. (2018). China's manufacturing locus in 2025: With a comparison of "Made-in-China 2025" and "Industry 4.0." Technological Forecasting and Social Change, 135, 66-74. https://doi.org/10.1016/j.techfore.2017.05.028

Liao, Y., Deschamps, F., Loures, E. de F. R., \& Ramos, L. F. P. (2017). Past, present and future of Industry 4.0 - a systematic literature review and research agenda proposal. International Journal of Production Research, 55(12), 3609-3629. https://doi.org/10.1080/00207543.2017.1308576

López González, J., \& Sorescu, S. (2019). Helping SMEs internationalise through trade facilitation, OECD Trade Policy Papers, 229, 1-65. https://doi.org/10.1787/2050e6b0-en

Manolova, T. S., Brush, C. G., Edelman, L. F., \& Greene, P. G. (2002). Internationalization of Small Firms: Personal Factors Revisited. International Small Business Journal, 20(1), 9-31. https://doi.org/10.1177/0266242602201003

Ministry of the Economy and Innovation of the Republic of Lithuania. (2019). https://eimin.lrv.lt/en/sector-activities/business-environment/small-and-medium-sizedbusiness (59), 1-77.

OECD. (2015). Internationalisation of SMEs (Dimension 10) in Eastern partner countries. In SME Policy Index: Eastern Partner Countries 2016: Assessing the Implementation of the Small Business Act for Europe, 1-313. https://doi.org/10.1787/9789264246249-17-en

OECD. (2017). OECD Digital Economy Outlook 2017. OECD Digital Economy Outlook 2017, 9789264276.

Podvezko, V. (2004). Ekspertų ịverčių suderinamumas. Technological and Economic Development of Economy, (2), 101-107. https://doi.org/10.3846/13928619.2005.9637688 
Ratten, V., Dana, L. P., Han, M., \& Welpe, I. (2007). Internationalisation of SMEs: European comparative studies. International Journal of Entrepreneurship and Small Business, 4(3), 361-379. https://doi.org/10.1504/IJESB.2007.013257

Roblek, V., Meško, M., \& Krapež, A. (2016). A Complex View of Industry 4.0. SAGE Open, 6(2), 215824401665398. https://doi.org/10.1177/2158244016653987

Schwab, K. (2017). The Fourth Industrial Revolution. National Academies of Sciences, Engineering, and Medicine Proceedings of a Workshop-in Brief. Washington, DC: The National Academies Press. https://doi.org/10.17226/24699

Sekliuckiene, J. (2013). Lithuanian Companies in Emerging Markets: Internationalization Motives and Barriers. Economics and Management, 18(1), 124-133. https://doi.org/10.5755/j01.em.18.1.3782

Skudiene, V., Auruskeviciene, V., \& Sukeviciute, L. (2015). Internationalization Model Revisited: E-marketing Approach. Procedia - Social and Behavioral Sciences, 213, 918924. https://doi.org/10.1016/j.sbspro.2015.11.505

Solano Acosta, A., Herrero Crespo, Á., \& Collado Agudo, J. (2018). Effect of market orientation, network capability and entrepreneurial orientation on international performance of small and medium enterprises (SMEs). International Business Review, 27(6), 1128-1140. https://doi.org/10.1016/j.ibusrev.2018.04.004

Sommer, L. (2015b). Industrial Revolution - Industry 4.0: Are German Manufacturing SMEs the First Victims of this Revolution? Journal Of Industrial Engineering And Management, 8(5), 1512-1532. https://doi.org/10.3926/jiem.1470

Wong, J.-M. (2011). A Relational View of Resources-based Theory: The case of Internationalization of Li \& Fung Group. The Journal of Human Resource and Adult Learning, 7(2), 34-39.

Xu, L. Da, Xu, E. L., \& Li, L. (2018). Industry 4.0: state of the art and future trends. International Journal of Production Research, 7543, 1-22. https://doi.org/10.1080/00207543.2018.1444806

Zapletalová, Š. (2015). Models of Czech companies' internationalization. Journal of International Entrepreneurship, 13(2), 153-168. https://doi.org/10.1007/s10843-015-0145-9

Zhou, K., Liu, T., \& Zhou, L. (2016). Industry 4.0: Towards future industrial opportunities and challenges. 2015 12th International Conference on Fuzzy Systems and Knowledge Discovery, FSKD 2015, 2147-2152. https://doi.org/10.1109/FSKD.2015.7382284

\section{AUTHORS' SHORT BIOGRAPHIES}

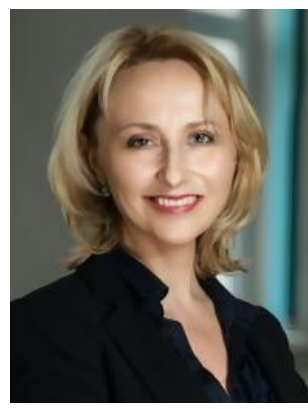

Kristina Kovaite is researching the effectiveness of Industry 4.0 driven transformations and disruption business models and economic impact on business, society and environment as her topic for $\mathrm{PhD}$ studies at Vilnius Gediminas Technical University, Lithuania. She undertook internship at Laussane Ecole Polytechnique Federale de Lausanne, University College London, Universidad Politecnica de Madrid, etc. Kristina Kovaite has participated in the international conferences.

Before Kristina has been involved in projects and now she actively works on international research project development.

Address: Sauletekio Av. 11, LT-10223, Vilnius, Lithuania.

E-mail: kristina.kovaite@ vgtu.lt

ORCID iD: https://orcid.org/0000-0003-4362-8001 

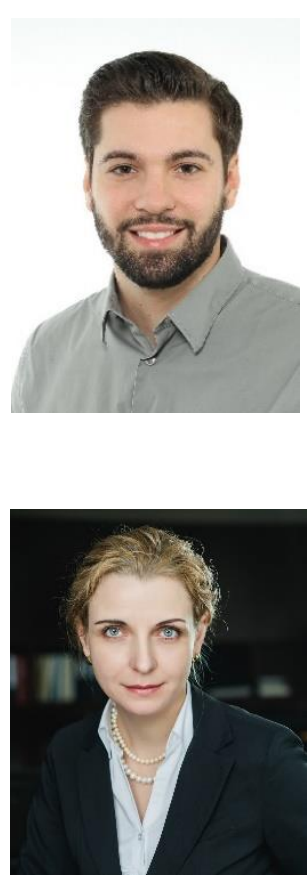

Paulius Šūmakaris has been working in small and medium-sized enterprises as an Export mMnager or Head of Sales and Marketing since 2011. He received the Master's degree in Business Management from Vilnius Gediminas Technical University, Lithuania, in 2018. His main research areas include internationalization driving and hindering factors driving and hindering internationalisation in small and medium-sized-enterprises, nontechnological innovation, innovation impact on export strategy, social and human capital.

Address: Sauletekio Av. 11, LT-10223, Vilnius, Lithuania

E-mail: paulius@sumakaris.lt

ORCID iD: https://orcid.org/0000-0002-0460-2143

Jelena Stankevičienė, Dr., Professor, Dean of the Faculty of Business Management at Vilnius Gediminas Technical University, Lithuania. She holds an excellent record as an entrepreneurship, economics and finance expert. Her main research topics include financial management for value creation and value engineering. She is the editor-in-chief of periodical peerreviewed scientific journal abstracted by international databases and a chairman and a member of the scientific committee of international conferences. Prof. Jelena Stankevičiene is the author of more than 50 scientific publications indexed in the Web of Science, Scopus, Ebsco, Emerald and other databases.

Address: Sauletekio Av. 11, LT-10223, Vilnius, Lithuania

E-mail: jelena.stankeviciene@vgtu.lt

ORCID iD: https://orcid.org/0000-0002-5600-5842

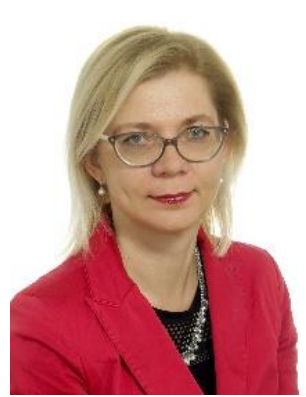

Renata Korsakienè received the $\mathrm{PhD}$ degree in Management and Administration from Vilnius Gediminas Technical University, Lithuania, in 2001. She is a Professor at Vilnius Gediminas Technical University, Lithuania. She had taken senior positions in domestic private and public companies. Dr Korsakiene has been a Visiting Professor at the universities in the Netherlands, Switzerland, Finland, Spain, Portugal, Turkey, etc. Her papers have been published in different academic journals such as Sustainability, Soft Computing, Economic Research (ekonomska istrazivanja), Transformations in Business and Economics, Journal of Business Economics and Management, Technological and Economic Development of Economy, Entrepreneurial Business and Economics Review and others. She has also published different books about Strategic Management and Human Resource Management. Her research interests include internationalisation, international entrepreneurship, human and social capital, regional development issues.

Address: Sauletekio Av. 11, LT-10223, Vilnius, Lithuania.

E-mail: renata.korsakiene@vgtu.lt

ORCID iD: https://orcid.org/0000-0002-4119-4521 